\title{
Effects of Some Insecticides on the Midgut of the Foragers Honeybee Worker Apis mellifera jemenatica
}

\author{
Dalal Musleh Aljedani, Mohammed Hamad Shiboob* and Roqaya Mohammed Almehmadi \\ Department of Biology, Faculty of Sciences - Al Faisaliah, \\ * Department of Environmental Science Faculty of Meteorology, Environment and Arid Land \\ Agriculture, King Abdulaziz University, Jeddah, Saudi Arabia.
}

\begin{abstract}
This study aims to evaluate the toxic effects of insecticides on the foragers honey bee workers, Apis mellifera jemenatica. It tracks the effects of the insecticides, Deltamethrin, Malathion and Abamectin through the feeding by mouth, on the midgut epithelial layer, in order to show the histological changes. Histological study on samples of the foragers honey bee workers, after exposure to insecticides for 24 hours, was chosen as the average -concentration of the insecticide concentrations, which were used for each as follows: Deltamethrin $2.50 \mathrm{ppm}$, Malathion $3.125 \mathrm{ppm}$ and Abamectin $0.1 \mathrm{ppm}$, in addition to the control group. Studying the effect of each insecticide individually and then comparing the reaction and impact of these insecticides on the tissue of midgut has showed that the insecticide Malathion was more harmful to epithelial tissue midgut in honey bees cells than Abamectin, while Deltamethrin had the least effect. Therefore, the life of the foragers honeybee worker depends upon the health and safety of the entire members of the beehive, so it is necessary to take into account, when using the application of insecticides, the continuity of life of the entire society adoption of individuals beehive on worker bees layer depends on their life on this layer of the bee community.
\end{abstract}

Keywords: Insecticides, Midgut, Foragers honeybee workers, Apis mellifera jemenatica.

\section{Introduction}

The honey bee (Apis mellifera L.) is the most sensitive type of insects to pesticides (Melissa and Jeffrey 2010). The use of pesticides strongly affects, the colonies, leading to a great loss for beekeepers. It has been found that the bees die due to pesticides and not because of any other factor (Barnett et al., 2007).

The digestion and absorption of pesticide occur in the stomach. (Chapman, 1978;Snodgrass, 1984; Cruz-Landim, et al., 1996, Snodgrass and Erickson, 2003).

The stomach wall consists of three layers: inner epithelial, the median basement membrane, and the outer muscular coat (Chapman, 1978 and Snodgrass, 1984). Epithelial gut includes different types of cells, such as Amadiyah cells consist columnar, regenerative and glands (Goblet cells). The columnar cells are the most prevalent types of cells in honey bees epitheliallayer, and they have Striated border in the apical surface, consisting of a regular cylindrical extensions and cilia (cylindrical microvilli) (Cruz-Landim, 1985).

The function of epithelial cells in the insect midgut is the secretion of enzymes and absorption of nutrients digested (Harvey and Blankemeyer, 1975).

The results of a comparative histological structure study of midgut for the queen and workers honeybees in pupal and adult stages indicated that the queen tissue was more advanced than the worker, and that there was a clear impact on the food type on the midgut structure (Aljedani et al., 2010).

The interactions between the different stresses in honeybees may be partly responsible for losses in honey bee colonies that have been confirmed all over the world 
for more than ten years. (Oldroyd, 2007; Potts et al., 2010; VanEngelsdorp and Meixner, 2010). Detoxification and immune processes are rapid in insects to biochemical stress (Lemaitre and Hoffmann, 2007). This is clearly shown in the midgut (Hao et al., 2003; Pauchet, et al., 2009). Given that this part (midgut) is subject to many stresses, and it is a key location for a all materials that are taken through the bee's mouth (Aufauvre, et al., 2014).

The insecticides are classified into three groups: stomach poison, contact poison, and fumigant (David and Ananthakrishnan, 2004). The insecticides entry takes place through three routes: orally into the stomach, contact through the integument, and through the spiracles (fumigants) (Atkins,2003). Most studies have focused on mortality or behavioral deficiency in behavior honeybees while neglecting other physiological functions and target organs. The midgut epithelium of honeybees presents an important interface between the insect and its environment (Forkpah et al., 2014).

Midguts of adult worker bees are simple, sshaped tubes of epithelium cells, which originate at the base of the periventricular valve and terminate at the pyloric valve of the small intestine. An elaborate network of tracheae supplies the midgut tissues through small traceless that infiltrate deep intracellular channels in the gut surface (Jimenez and Gilliam, 1990).

During metamorphosis, the larval midgut epithelium degenerates and a new adult midgut epithelium is built during larval differentiation of regenerative cells. Regenerative cell proliferation was detected during larval lifespan (Martins, et al., 2006).

The use of pesticides in areas where the bees spread could severely affect the colonies. In this case it is important that bees would die due to pesticides, not from other factors. Where that midgut is responsible for the absorption digestion of food and other materials, decomposing them simple materials, utilized in the vital and necessary life processes. So, the aim of this study is follow up the midgut changes following exposure to insecticides.

\section{Materials and Methods}

The field research has been conducted in the apiary of Hada Al Sham Research Station, King Abdulaziz University, which is a model station for agricultural research in the Kingdom.

\section{Honeybee races used in the study}

Yemeni bee race (local) Apis mellifera jemenatica, has been subjected to this research. This strain was defined for the first time by the German scientist, (Ruttner, 1975). It is one of the yellow bee strains spread in many parts of the Arabian Peninsula, distinctive of its adaptation under environmental conditions prevailing in Saudi Arabia, and for its disease resistance. (AlGhamdi, 2002).

\section{Individuals used in the study}

Foragers honeybee workers were chosen to conduct this study according to Oldroyd and Nanork, (2009), Khoury et al.,(2011), where two methods were combined for the design of wooden cages for breeding, taking into account that one face of the wooden box is covered with metal wire mesh, while the opposite face was of glass, based on what was mentioned by Kakmand et al.,(2008), and for holding cage measurements, $(40 \times 30$ $\times 30 \mathrm{~cm}$ ).

\section{Material and food administration}

The cage was provided, on the top side with 2 plastic medical syringe $(50 \mathrm{ml})$, one of which with water, and the other syringe with sugar solution of $(50 \%)$ as a source of carbohydrate nutrition (Bortolotti, et al., 2003; Medrzycki, et al., 2003; Pohorecka, 2004), laced with the insecticide solution under test. The cage was also provided with a small plastic pot of $3 \mathrm{~cm}$ in diameter, and $1 \mathrm{~cm}$ in height, put in the cage bottom to provide natural protein nutrition, (pollen) mixed with 
sugar in equal parts; where 50 grams of pollen and 50 grams of powdered sugar as well as a little water were added to get a paste, and then 10 grams of the paste were put in the plastic pot, covered with a transparent perforated plastic sheet to allow feeding of bees and protection of the paste (dough) from drying out and preventing the adhesion of such food particles to bees during feeding.

\section{The period of experiments}

The insecticides entry takes place through there nonfat: orally into the stomach, contact through the integument, and through the spiracles (fumigants), representing the most prevalent groups, available in abundance in the Saudi market,: Deltamethrin; a compound of Pyrethroid group, Malathion, from the Organophosphates pesticide group, and Abamectin pesticide, from the Avermectin group as bees midgut poisons.

\section{Study groups division}

Bees were divided into four groups:

1. Non-exposed (control);

2. Deltamethrin exposed ( $2.50 \mathrm{ppm})$;

3. Malathion, exposed (3.125 ppm); and

4. Abamectin, exposed (0.1 ppm).

\section{Study procedures}

All bee groups were provided with water and natural protein nutrition and sugar solution laced with insecticides in the concentration described. After initial tests, the appropriate concentration of each pesticide was selected.

The control group was fed naturally, with water, natural protein nutrition as well as sugar solution, free of any additives. The colony was being monitored for death; a bee would be considered dead if it remained motionless for ten-second observation, to be removed gently by a fine brush (Laurino, et al., 2013). The experiment was repeated three times using fifteen insects in each time.

Sampled from the studied honey bees were subjected to the following procedure: The Specimens was: 1) fixed Trump's fixative. 2)
Rinse tissue twice in distilled water. 3) Fix in Osmium Tetroxide. 4) Rinse tissue twice in distilled water. 5) Uranyl acetate. 6)70\% Ethanot. 7) 95\% Ethanol. 8) 100\% Ethanol. 9) Propylene oxide two changes. 10) Propylene oxide Resin (1:1). 11) Resin infiltration pure. 12) Embedding in pure resin into blocks at $60^{\circ} \mathrm{C}$. The blocks were cut using automatic rotary microtome (LEICA EM UC6). For studying general structure, the Toluidine Blue stains were used. then examined and photo by microscope (Olympus-Bx51).

\section{Results and Discussion}

The midgut epithelium cells of the bees fed by sugar solution (the control), as shown in (Figure1 $(\mathrm{A})(\mathrm{B})(\mathrm{C})$, possess normal nucleus, homogenous cytoplasm inclusion with intact and regular cell boundary; they have a striated border ( $\mathrm{Sb}$ ) at the apex. The most abundant type of epithelium cells is columnar cells that are arranged in one layer and settled on the basement membrane $(\mathrm{Bm})$, another type of epithelium which could be observed is regenerative cells; their terminals did not reach the lumen $(\mathrm{L})$, these were in agreement with (Cruz-Landim,(1985); Serrao and CruzLandim,(1995);Cruz-Landim and Cavalcante (2003); and Kakmand, et al., (2008)).

The midgut endocrine cells of insects, generally, are not easily identified by light microscope(Neves et al., 2003).The columnar epithelium cells are the functional, digestive cells; regenerative cells serve to regenerate the damaged functional cells (Serrao and CruzLandim,1995;Cruz-Landimet al.,1996). 


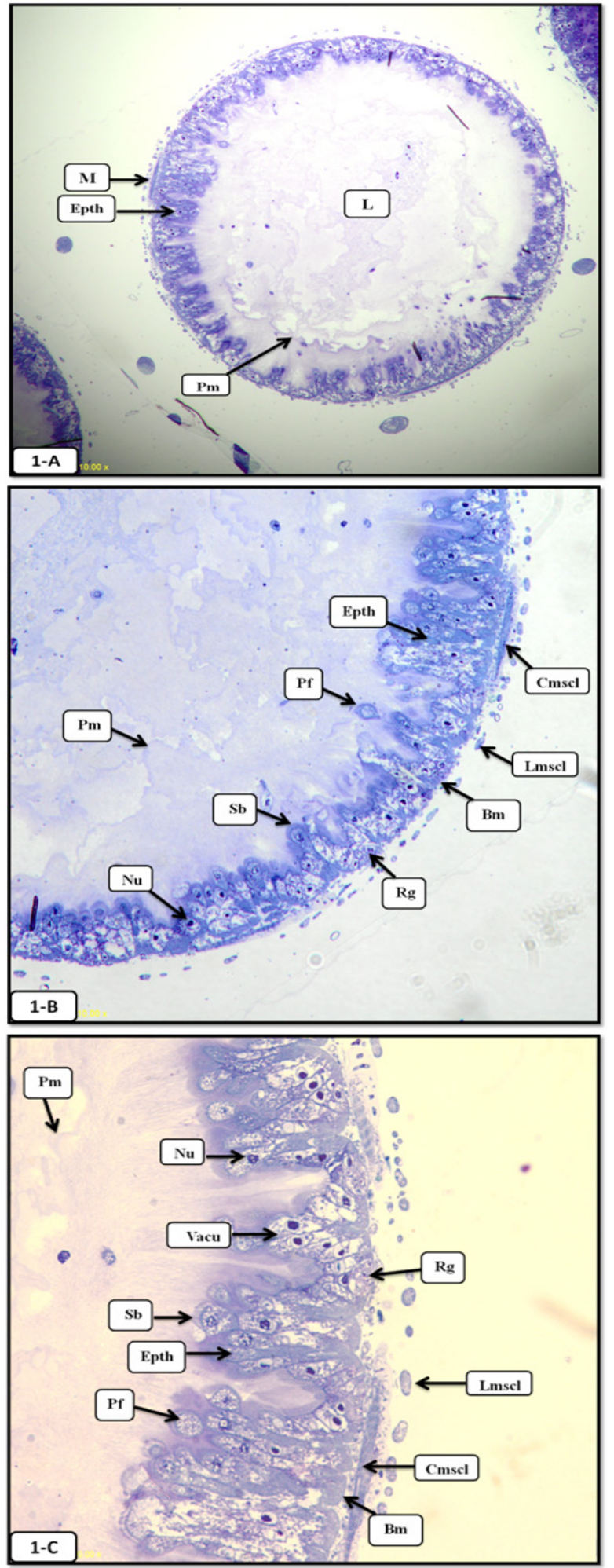

Fig. 1. $(\mathrm{A}-10.00 \mathrm{X})(\mathrm{B}-10.00 \mathrm{X})(\mathrm{C}-20.00 \mathrm{X})$ : Cross section of the midgut in the foragers honey bee workers after 24hr. of control group. Bm: basement membrane, Cmscl: circular muscles, Epth: epithelium cells, L:lumen, Lmscl: longitudinal muscles, M: muscles, Nu: nucleus, Pm:peritrophic membrane, Pf: proliferating small epithelium digestive cells, Rg:regenerative cells, Sb: striated border., Vacu: vacuoles.
In the current study, the columnar epithelium cells(Epth) appeared in multiple and cumulative layers on top of each other and the cell membrane was not affected by Deltamethrin, while with Malathion the cells were clearly without boundaries between them and the cell membrane was ruptured, with components mixed with each other. With Abamectin, the cells border was not well apparent, and the cell membrane was affected. Spread of cytoplasmic vacuoles (Vacu) was observed in epithelium columnar of Deltamethrin exposed cells, and when exposed to the Malathion, thes vacuoles were too many at bases of cells, and on the top of exposed cells, with exposure to the Abamectin, it could be recovered by eliminating the insecticide doses that generated them, as a detoxifying capacity of the cells. Honey bees, as with other insects, possess various detoxifying enzymes that might be expected to protect them from insecticide poisoning $\mathrm{Yu}$, et al., (1984).

Epithelium cell's nuclei $(\mathrm{Nu})$ were natural and clear under of exposure to Deltamethrin and Abamectin, while with Malathion they were abnormal and cannot be clearly discerned, and become cells with tops ruptured and decomposed striated border $(\mathrm{Sb})$ when exposed to all insecticides.

The regenerative cells $(\mathrm{Rg})$ that develop clearly beside cells' bases under exposure to Deltamethrin, while under Malathion no clear cell border was seen at the bases of epithelium cells under Abamectin exposure, cell burblers demonstrated varying degree of growth.

The presence of an epithelium layer cells of the proliferating small epithelial digestive cells (Pf) as small buds arise from stomach epithelium, which intern arise from the division of epithelial cells under exposure to Deltamethrin, while with both Malathion and Abamectin they were very few.

When midgut epithelial cells were exposed to Malathion and Abamectin, the peritrophic membrane $(\mathrm{Pm})$ was decomposed, while it was normal when exposed to Deltamethrin. Epithelial cells stabilized at the basement membrane $(\mathrm{Bm})$, and the cell membranes are 
completely degenerated, especially under Malathion. These results are agreement with Kakmand, et al. (2008).

Midgut epithelium, surrounded from outside by a layer of muscles (M); circular muscle (Cmscl) from inside and longitudinal muscles from outside (Lmscl) degenerated when exposed to all of these pesticides.

The midgut epithelial tissue of the bees, orally treated with the minimal concentration of deltamethrin, malathion and thiamethoxam, appeared to be slightly affected by these insecticides. Their nuclei were abnormal, bounded by large vacuoles, the cytoplasm was dense, coarse particularly when associated with malathion and scattered inclusion. The cell membrane was not affected and appeared to be still intact, except under malathion .

Many vacuoles with various sizes could be seen in under exposure to malathion and thiamethoxam in comparison with deltamethrin. The insecticides' actions were clearly observed on the midgut epithelial cells of the bees treated with the three insecticides.

The abnormality of their nuclei was clearly observed, their cytoplasm granulated, vacuolated, and the cell membrane disrupted, specifically under exposed to $3.125 \mathrm{ppm}$ malathion.

The midgut epithelial layer of the bees treated with 5, 6.25 and $0.125 \mathrm{ppm}$ deltamethrin, malathion and thiamethoxam, respectively, was disrupted and most cells had exploded, especially with malathion.

The nuclei had disappeared or diminished in three cases, the cytoplasm inclusionwas scattered and the cell membranes were decayed completely as in case of exposure to $6.25 \mathrm{ppm}$ malathion. Some cells were separated from the basement membrane, particularly by the action of $5 \mathrm{ppm}$ Deltamethrin and $6.25 \mathrm{ppm}$ Malathion.

In this case the affected cells could be replaced by new intact cells as long as the regenerative cells exist, or recovered by eliminating the insecticide doses that vacuolated as a detoxifying capacity of the cells
(Kakmand, et al., 2008). (Figures 2(A,B);3(A,B); 4(A,B))

The present study showed that Malathion was more harmful to the epithelial tissue midgut cells in honey bees, followed by Abamectin. Deltamethrin had the least impact on the histological structure of midgut.

In conclusion, the use of insecticides affect the safety of the foragers honey bee workers. Study has shown that the midgut cells affected by insecticides and clear effects depending on the insecticide used malathion was clear effect on epithelial cells of midgut. Therefore, it is important to study the vital functions and target organs when using insecticides, and try to identify the impact of insecticides on the internal organs and changes in the incident and its impact on its functions and vitality.

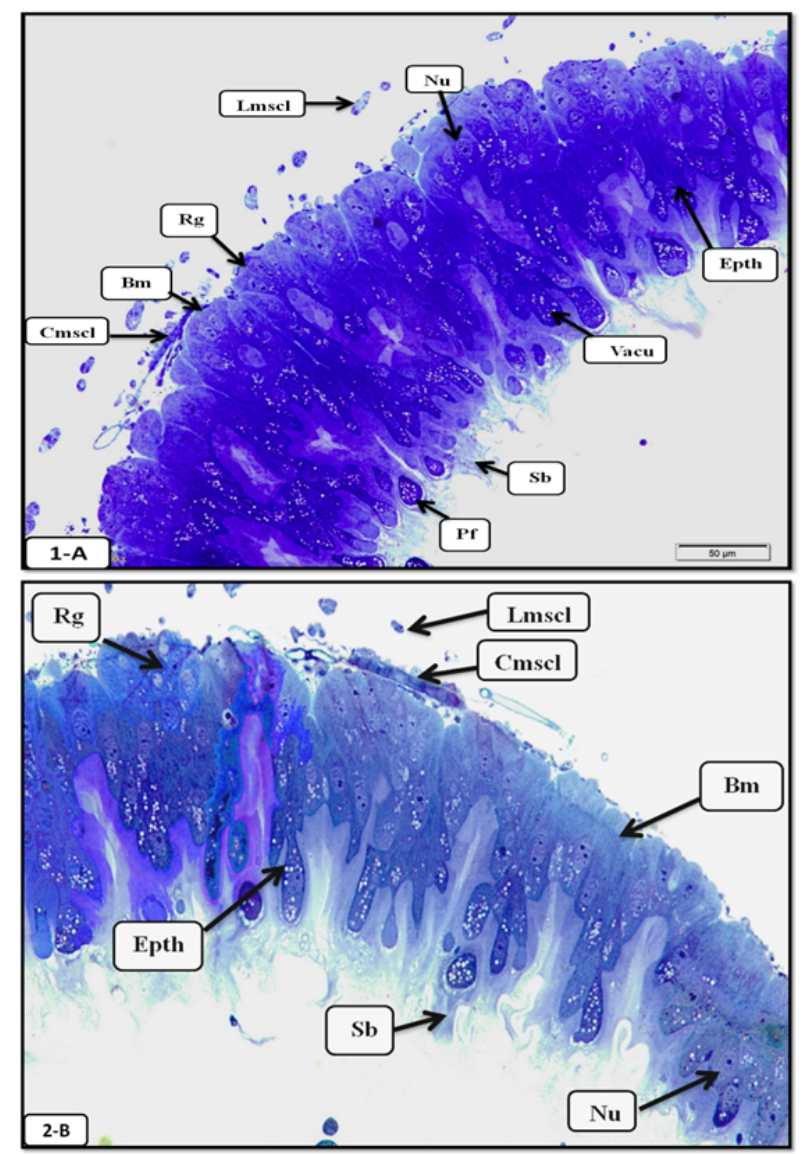

Fig. 2. (A-20.00X) (B-20.00X): Cross section of the midgut in the foragers honey bee workers after $24 \mathrm{hr}$. of exposure of Deltamethrin, with $2.50 \mathrm{ppm}$ concentration. Bm: basement membrane, Cmscl: circular muscles, Epth: epithelium cells, Lmscl: longitudinal muscles, Nu: nucleus, Pf:proliferating small epithelium digestive cells, Rg:regenerative cells, Sb: striated border., Vacu: vacuoles. 

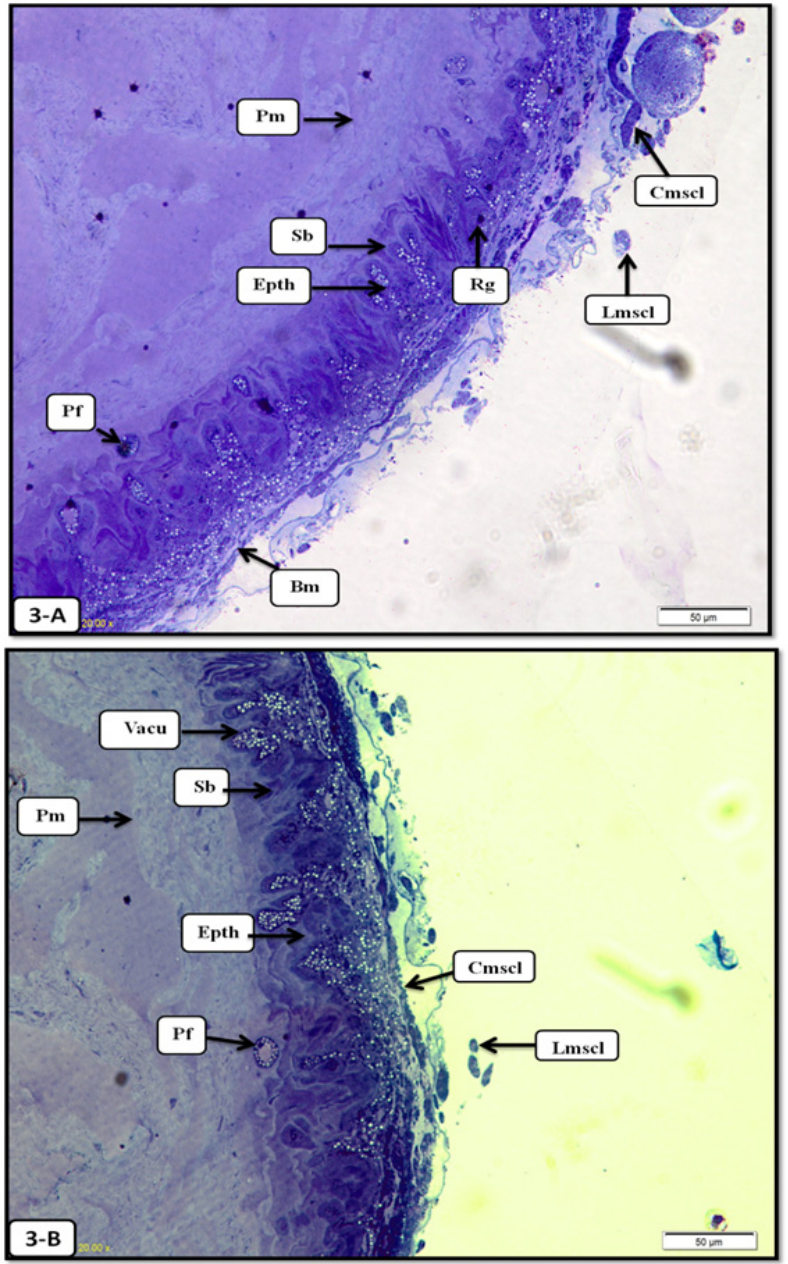

Fig. 3. (A-20.00X) (B-20.00X): Cross section of the midgut in the foragers honey bee workers after $24 \mathrm{hr}$. of exposure of Malathion, with 3.125 ppm concentration. Bm: basement membrane, Cmscl: circular muscles, Epth: epithelium cells, Lmscl: longitudinal muscles, Pm:peritrophic membrane, Pf: proliferating small epithelium digestive cells, Rg:regenerative cells, Sb: striated border. , Vacu: vacuoles.

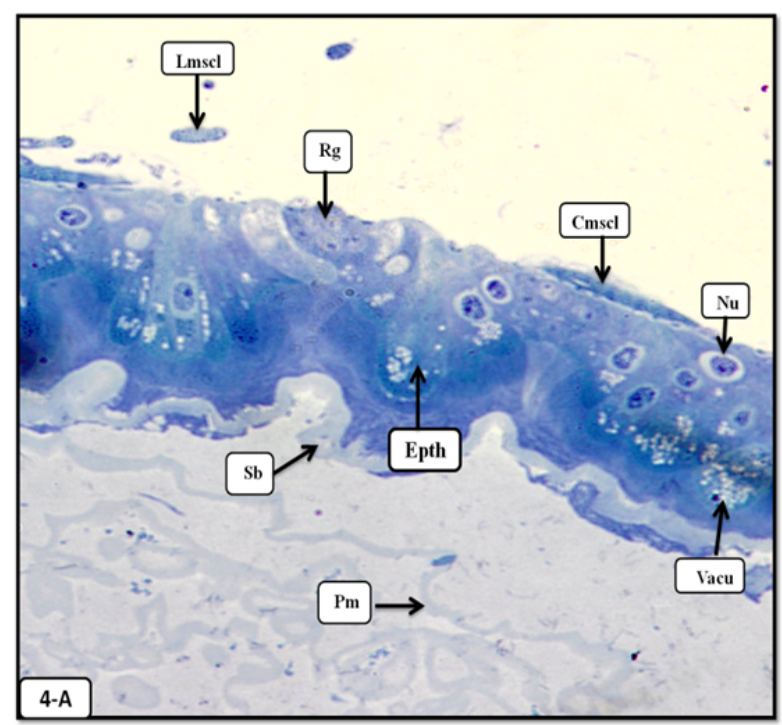

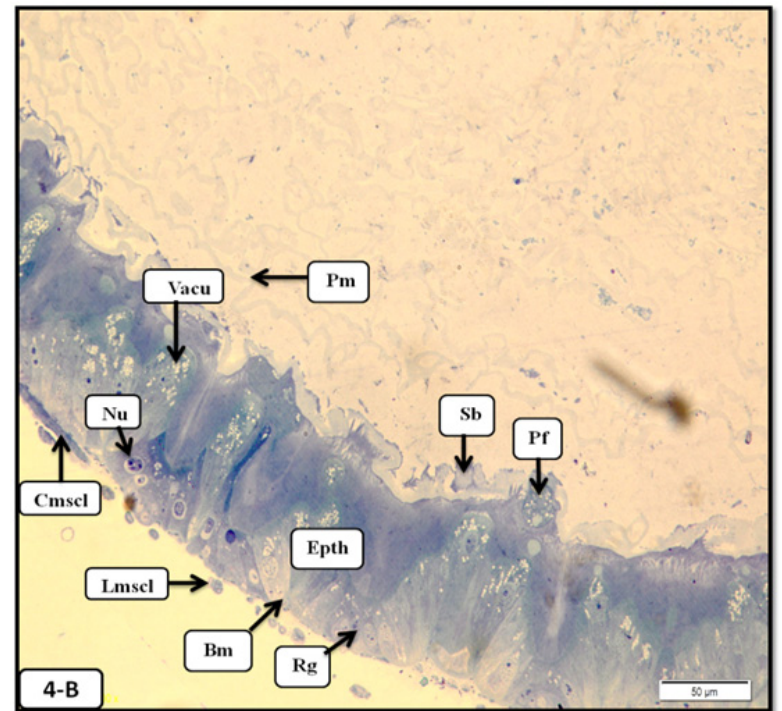

Fig. 4. (A-20.00X) (B-20.00X):Cross section of the midgut in the foragers honey bee workers after $24 \mathrm{hr}$. of exposure of Abamectin, with 0.1 ppm concentration. Bm: basement membrane, Cmscl: circular muscles, Epth: epithelium cells, Lmscl: longitudinal muscles, Nu: nucleus, Pm:peritrophic membrane, Pf: proliferating small epithelium digestive cells, Rg:regenerative cells, $S b$ : striated border., Vacu: vacuoles.

\section{References}

Al-Ghamdi, A.A. (2002) The effect of pollen supplementary feeding on some activities of honeybee colonies during summer season in Riyadh, Saudi Arabia, Saudi. J. Biol.Sci, 9 (2): 85-94.

Aljedani, D.M., Alghamdi, A.A. and Almehmadi, R.M. (2010) Comparative study in midgut histological structure of queen and worker yemeni honey bees Apis mellifera jemenatica (Hymenoptera: Apidae) in pupae and adult stages under natural nutrition, Ass. Univ. Bull. Environ. Res, 13 (2): 63-76.

Atkins, E.L. (2003) The hive and the honey bee: injury to honey bees by poisoning, edit by Graham, J.M. Revised ed. Dadant and Sons, Hamilton, Illionis, U.S.A, pp: 11531208.

Aufauvre, J., Misme-Aucouturier, B., Vigue`s, B., Texier, C. and Delbac, F. (2014) Transcriptome analyses of the honeybee response to Nosema ceranae and insecticides, PLOS ONE, 9 (3): 1-12.

Barnett, E.A., Charlton, A.J. and Fletcher, M.R. (2007) Incidents of bee poisoning with pesticides in the United Kingdom1994-2003, Pest Manag. Sci, 63 (11): 10511057.

Bortolotti, L., Montanari, R., Marcelino, J., Medrzycki, P., Maini, S. and Porrini, C. (2003) Effects of sub-lethal imidacloprid doses on the homing rate and foraging activity of honey bees, Bull, Insectol, 56 (1): 63-67.

Chapman, R. F. (1978) The Insects structure and function, Engl. Univ. Press. Ltd, London, England, p. 819.

Cruz-Landim, C. (1985) Ultra-estructura e funçăo do tubo digestivo dos insetos, Aciesp, 44: 28-29.

Cruz-Landim, C. and Cavalcante, M.V. (2003) Ultrastructural and cytochemical aspects of 
metamorphosis in the midgut of Apis mellifera L. (Hymenoptera, Apidae: Apinae), Zool. Sci, 20: 1099-1107.

Cruz-Landim, C., Silva-de-Moraes, R. L. and Serrão, J. E. (1996) Ultrastructural aspects of epithelial renewal in the midgut of adult worker bees (Hymenoptera, Apidae), $J$. Comp. Biol, 1 (1/2): 29-40.

David, B. V. and Ananthakrishnan, T. N. (2004) General and applied entomology, $2^{\text {nd }}$ ed. Tata McGraw-hill Publishing Co. Ltd. New Delhi. India., p.1184.

Forkpah, C., Dixon, L.R., Fahrbach, S.E. and Rueppell, O. (2014) Xenobiotic effects on intestinal stem cell proliferation in adult honey bee (Apis mellifera L.) workers, PLoS One, 9 (3): 1-9.

Hao, Z., Kasumba, I. and Aksoy, S. (2003) Proventriculus (cardia) plays a crucial role in immunity in tsetse fly (Diptera: Glossinidiae), Insect Biochem Mol Biol, 33: 1155-1164.

Harvey, W.R. and Blankemeyer, J.T. (1975) Epithelial structure and function, In: Maramorosch K. and Shope, R.E, eds. Invertebrate Immunity. Academic Press, New York, pp: 3-22.

Jimenez, D.R. and Gilliam, M. (1990) Ultrastructure of the ventriculus of the honey bee, (Apis mellifera L.) cytochemical localization of acid phosphatase, alkaline phosphatase, and nonspecific esterase, Cell Tissue Res, 261:431- 443.

Kakmand, F. A ., Mahmoud, T. T . and Amin, A.M. (2008) The role of three insecticides in disturbance the midgut tissue in honeybee Apis mellifera L. workers, Kurdistan $1^{\text {st }}$ Conference on Biological Sciences, J. Dohuk Univ, 11: (1): 144-151.

Khoury, D.S ., Myerscough, M. R. and Barron, A. B. (2011) A quantitative model of honey bee colony population dynamics, PLOS ONE, 6(4): 1-6.

Laurino, D., Manino, A., Patetta, A. and Porporato, M. (2013) Toxicity of neonicotinoid insecticides on different honey bee genotypes, Bulletin of Insectology, 66 (1): 119 126.

Lemaitre, B. and Hoffmann, J. (2007) The host defense of Drosophila melanogaster, Annu Rev Immunol, 25: 697743.

Martins, G.F ., Neves, C.A., Campos, L.A. and Serrão, J.E. (2006) The regenerative cells during the metamorphosis in the midgut of bees, Micron, 37 (2): 161-168.

Medrzycki, P., Montanari, R., Bortolotti, L., Sabatini, A.G., Maini, S. and Porrini, C. (2003) Effects of imidacloprid administered in sublethal doses on honey bees' (Apis mellifera L.) behaviour. Laboratory tests, Bull. Insectol, 56 (1): 59-62.

Melissa, H. C. and Jeffrey, S. G. (2010) Is Apis mellifera more sensitive to insecticides than other insects? , Pest Management Science, 66 (11): 1171-1180.

Neves, C.A., Gitirana, L.B. and Serrão, J.E. (2003) Ultrastructural study of the metamorphosis in the midgut of Melipona quadrifasciata athidioides (Apidae .Meliponini) worker, Sociobiology, 41: 443-459.

Oldroyd, B. P. (2007) What's killing american honey bees?, PLoS Biology, 5 (6): 1195- 1199.

Oldroyd, B. P. and Nanork, P. (2009) Conservation of Asian honey bees, Apidologie, 40: 296-312.

Pauchet, Y., Freitak, D., Heidel-Fischer, H.M., Heckel, D.G. and Vogel, H. (2009) Immunity or digestion: glucanase activity in a glucan-binding protein family from Lepidoptera, J Biol Chem, 284: 2214-2224.

Pohorecka, K. (2004) Effect of standardized plant herb extracts on general condition of the honey bee (Apis mellifera L.), Bull. Vet. Inst. Pulawy, 48: 415-419.

Potts, S.G., Biesmeijer, J.C., Kremen, C., Neumann, P., Schweiger, O. and Kunin, W.E. (2010) Global pollinator declines: trends, impacts and drivers, Trends Ecol Evol, 25: 345-353.

Ruttner, F. (1975) Africa races of honey bees, $25^{\text {th }}$ prec Int, beekeep.Apic. Congr. Apimondia, pp: 325-344.

Serrão, J .E. and Cruz-Landim ,C.D. (1995) Gut structures in adult workers of necrophorous neotropical stingless bees (Hymenoptera, Apidae, Meliponinae), Entomol Gener, 19 (4) : 261-265 .

Snodgrass, R.E. (1984) Anatomy of the honeybee. Comstock Publishing Associates, A division of cornell university press .Ithaca and London, Fourth printing, p. 332.

Snodgrass, R. E. and Erickson, E. H. (2003)The hive and the honeybee: The anatomy of the honey bee, Edit by Joe M. Graham. Revised Ed. Dadant and Sons. Hamilton, ILLINOIS. U.S.A.

Van Engelsdorp, D. and Meixner, M.D. (2010) A historical review of managed honey bee populations in Europe and the United States and the factors that may affect them, J. Invertebr, Pathol, 103 (1): 80-95.

Yu, S. J., Robinson, F. A. and Nation, J. L. (1984) Detoxication capacity in the honey bee, Apis mellifera $\mathrm{L}$. Pesticide, Biochem. and Physiol, 22: 360-368. 
تأثنير بعض المبيدات الحشرية على المعي المنوسط لشغالة نحل العسل السارحة Apis mellifera jemenatica

دلال مصلح الجدعاني، ومحمد حمد شيبوب"، ورقية محمد المحمادي

قسم علوم الأحباء، كلية العلوم بالفيصلية، "قسم العلوم البيئية، كلية الأرصاد والبيئة وزراعة الدناطق الجافة، جامعة الملك عبدالعزيز، جدة، المعلكة العربية السعودية

الدستخص. تهدف هذه الدراسة إلى تقييم الآثار السامة لبعض المبيدات الحشرية على شغالات نحل العسل

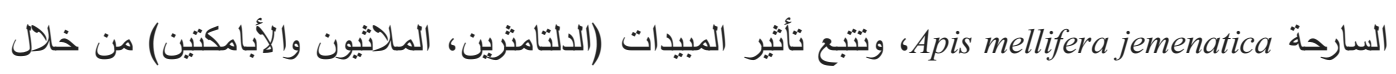

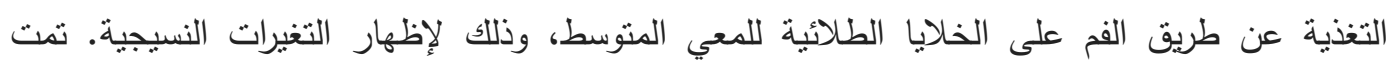

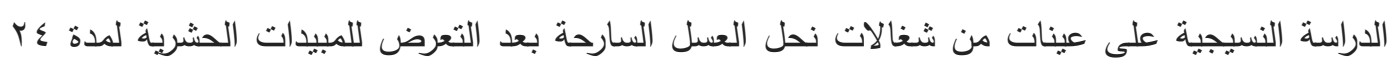

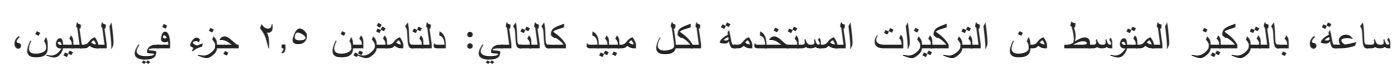

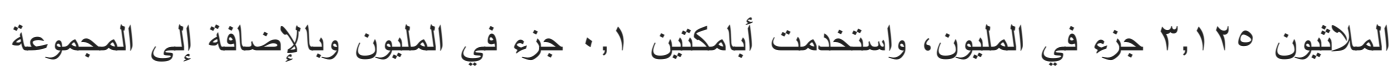

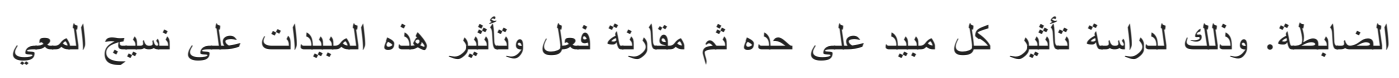

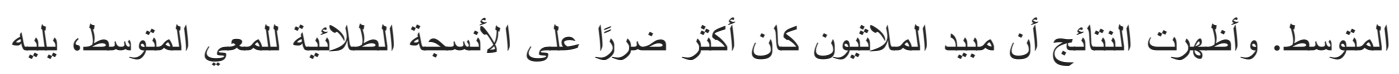

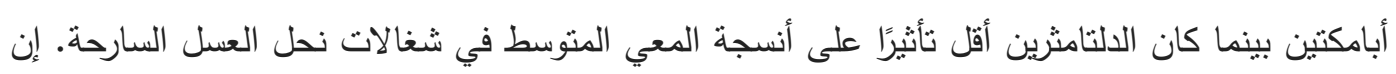

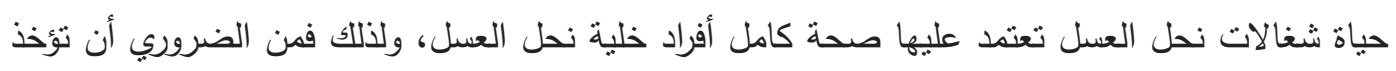

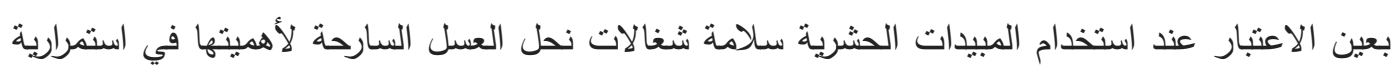
الحياة ولاعتماد مجتمع نحل العسل بأكمله من أفراد الخلية على هذه الطبقة (الشغالات).

الكلمات الدالة: المبيدات الحشرية، المعي المتوسط، شغالات نحل العسل السارحة، Apis mellifera -jemenatica 